\title{
The Causal Relationship between Inflation and Unemployment: Evidence from a Panel Analysis of COMESA
}

" The rate of change of money wage rates can be explained by the level of unemployment and the rate of change of unemployment, except in or immediately after those years in which there is a sufficiently rapid rise in import prices to offset the tendency for increasing productivity to reduce the cost of living "

(Phillips, 1958, 299)

\section{Seham Hamed Negem}

\author{
Faculty of Commerce \\ Tanta University \\ Egypt
}




\section{Abstract:}

For COMESA, the inflation and unemployment causality has been tested using Granger causality based on the Vector Error Correction Model (VECM). During the period 2000-2018, this paper indicates that in the short run there is a significant unidirectional relationship running from inflation to unemployment but not vice versa. The causal relationship in the long run has not been verified.

Key Words: Inflation, Unemployment, COMESA, Phillips Curve, Co integration, VECM. 


\section{Introduction:}

Is there a causal relationship between inflation and unemployment? And if this relationship exists, what is its direction? Is it unidirectional or bidirectional? This paper, empirically, tries to find out the existence of the relationship between inflation and unemployment by using panel data of the Common Market for Eastern and Southern Africa (COMESA21) countries.

Considered as key indicators and great macroeconomic problems of any economy, inflation and unemployment have been paid attention and debate concerning their relationship. Under full employment of an economy it is argued that this relationship does not exist at all. However, It began by the work of Phillips (1958), extended by Samuelson and Solow (1960). An inverse relationship between wages and unemployment was verified by Phillips.

He concluded that a fall in unemployment (higher employment) under a certain level, called natural level, could make an increase in wages and vice versa. However, as wages (real), price of labour in the labour market, represent the greatest components of prices, Samuelson and Solow (1960) concentrated on inflation rather than wages to affect inversely on unemployment.

Simply, the expectation of prices rising stimulates workers to demand higher wages to keep their real wages constant. In the short run, with higher growth rates and consequently higher wages, workers supply labour as a response of inflation accelerating and as a result an increase in the employment rate (a fall in the unemployment rate). Another explanation that is: with higher growth rates, in the short run, it is shown a positive relationship between output and the price level; however, it is a negative relationship between output and unemployment (Okun's law). This implies a negative relationship between inflation (the rise in the prices levels) and unemployment.

This paper attempts to contribute to the literature on the trade off between inflation and unemployment by applying on the COMESA countries. To the best of my knowledge, it is notable the absence of the COMESA application in the empirical work on the relationship between inflation and unemployment.

Granger causality test will be applied to investigate whether inflation changes result in or from the inverse changes of unemployment (if the relationship exists). Considering causality of inflation and unemployment, the remainder of this paper is organized as follows: section 2 presents the theory and some of empirical studies on the relationship between the two variables.

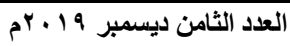


Then, the causality model is specified and methodology is demonstrated for the full sample of the COMESA21 countries panel data for the period 2000-2018. Using Give Win, Pc-Give of ( Doornik and Hendary, 2003), the specified model will be estimated to investigate the following tests: testing for stationary; Cointgration test; Granger causality test under Vector Autoregressive model (VAR) or Vector Error Correction Model (VECM), based on the results of the co integration test. And finally, the model results are introduced with concluding.

Inflation and unemployment: Theoretical Background and Empirical Evidence:

The inflation and unemployment relationship is shown in Phillips curve. Phillips (1958) proposed an inverse relationship between changes of wage and unemployment. He hypothesized that the level of unemployment and unemployment change rate can explain the change rate of the money wage rates (Phillips, 1958, 283). Using data of the United Kingdom for the period 1861-1957, Phillips tried to investigate the relationship between the variables stated in his hypothesis.

$\mathrm{He}$ concluded that there is a certain level of unemployment (natural level), as stated in section 1, in which the wage level is constant and a rapid increase in wages occurs when unemployment falls under its natural level. The Phillips' work was extended by Samuelson and Solow (1960) to reflect the inverse relationship between inflation (rather than wage) and unemployment in the short run. Their point of view is that wage represents the greatest component of prices, as stated, as it is a price of labour in the labour market.

As unemployment levels fall, inflation rises. This relationship, when sketched, considered inflation as the dependent variable, indicated on vertical axis and unemployment as the independent one indicated on the horizontal axis.

Samuelson and Solow (1960) considered the inflation and unemployment as a policy tool to increase the employment rate (a decrease of unemployment rate) at the expense of raising inflation rate (a percentage change in the price level). They used data for the period 19341958 of the United States to estimate the relationship between the inflation and unemployment rates and found, as mentioned, both variables inversely related.

A theoretical discussion about the Phillips curve, i.e., the inflation and unemployment relationship, was introduced by Maximova (2015). Her paper emphasized the connection between inflation and unemployment. This is in the short run; however, the connection is absent in the long run. So, inflation can be increased only as a result of 
government stimulation of aggregate demand to increase output at full employment.

Since presented by Samuelson and Solow (1960), the researchers pay more attention to the relationship between inflation and unemployment through the subsequent empirical studies. However, it is worth notable that most of them are based on time series data for one economy. Some studies are reviewed for finding out the shortages in the literatures and indicating the contribution of this paper.

Using time series data of Jordan for the period 1984-2011, ( AlZeaud, 2014), tried to investigate the trade-off relationship between unemployment and inflation. He found no relationship between the two variables. Furuoka (2008) reached the same conclusion for Philippines. However, a one way causality was found when applying on Malaysia stated in his work in 2007 (for more details, see Furuoke, 2007).

Also, using time series data of Indonesia for the period 19842017, (Sasongko and Huruta, 2019) concluded that unemployment causes inflation but not vice versa. By applying on the Nigerian economy, Abu (2017) found the existence of a causal relationship between inflation and unemployment in the long run using data for the period 1980-2016. However, using data for the period 1980-2015, on the same economy, yields a different conclusion that is: inflation affects unemployment in the short and long runs, running from inflation to unemployment (Stephen et al., 2017).

For the case of Greece form 1980 to 2010, a long run causal relationship was detected without indicating its direction (Dritsaki and Dritsaki, 2013).

As a significant contribution to the empirical analysis of inflation and unemployment literature, Bhattarai (2016), in depth, examined the issue of interest, unemployment-inflation trade-offs, in OECD countries. Based on his work, long run relations exist among OECD countries and the Phillips curve phenomena are still statistically significant for 28 out of 35 of OECD in panel data models and panel VAR model.

From reviewing these previous articles, it is worth notable that there is a gap in application using panel data and the absence of the COMESA application in the empirical studies on the relationship between inflation and unemployment, despite, from my point of view; it represents, empirically, a good case in this regard. Also, most of the literature reviewed estimate the traditional two-variable causality relationship.

This paper tries to overcome these shortages. This paper is going beyond the traditional two-variable causality relationship. A four-variable 
system is estimated to avoid any specification bias. Panel data techniques are applied to increase the test power. And finally, the COMESA data are used for the period 2000-2018.

\section{The Model Specification:}

The model specification, on analyzing the relationship between inflation and unemployment in the context of a causality test, is based on the Samuelson and Solow (1960) work to indicate the relationship between inflation and unemployment. Their work represents an extension of Phillips (1958) conclusion of the inverse relationship between wages and unemployment.

According to Samuelson and Solow (1960), inflation change could be inversely related to unemployment rather than wage change. A theoretical framework of incorporating search-generated unemployment into a model of international trade is used as well to specify the model (for more details, see the works of Negem, 2015; Hasan et al., 2010; and Dutt et al., 2008).

Based on the mentioned works, the aggregate unemployment function is simply written as follows:

$$
U=f(\text { inflation, protection) }
$$

Or, for more details, it can be written with the main selected variables of interest that represent inflation and protection as follows:

$$
U \cdot f\left(I N F, T A R_{\text {COMESA }}, T A R_{T P}\right)
$$

Where, $U$ is the unemployment rate, INF is the inflation rate, TAR $R_{\text {COMESA }}$ is the tariff applied by the COMESA to imports of its trading partners, $T A R_{T P}$ is the tariff applied to the COMESA exports by its trading partners (protection variables are for agricultural sector only). So, our model basic equation is:

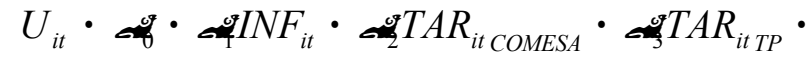

Where,

$t$ is the period from 2000-2018, enis independently distributed error term and $i$ is for a country.

For the linearity ensuring, the above function can be written with taking the logarithm as follows:

$$
\log U_{i t} \cdot \cos \cdot \log I N F_{i t} \cdot \log T A R_{i t C O M E S A} \cdot \log T A R_{i t T P} \cdot \operatorname{lit}
$$

As stated, Panel data techniques are applied to increase the number of observations and consequently, the test power. Also, going beyond the traditional two-variable causality relationship, a four-variable system is estimated to avoid any specification bias.

مجلة الاراسات التجارية المعاصرة




\section{Methodology:}

Data are pooled from COMESA21 countries for the period 20002018 and panel unit root tests and panel co-integration technique are employed to establish the long-run relationship between inflation and unemployment. The data set comprises annual measures for COMESA21 countries. This model is a four-variable system of unemployment rate (U), inflation rate (INF), TAR ${ }_{\text {COMESA }}$, and $T A R_{T P}$. The procedures are shown as follows:

\section{a- Unit root test:}

Using non-stationary data draws invalid inferences from the Granger causality test (for more details, see Negem, 2008). Im, Pesaran and Shin's (1998), IPS, panel unit root test technique is used to test for stationarity (determining the order of integration). The IPS statistic is mainly an average of the individual Augmented Dickey Fuller (ADF) statistics computed as t-bar statistics.

\section{b- Panel co-integration test:}

The presence or the absence of cointegration is examined, after investigating the integration order, to capture the long-run relationships among the variables. If there is no cointegration, the first difference of the data can capture these relationships, but if cointegration is present, they can not. The panel cointegration test can be specified in the context as follows:

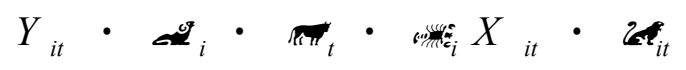

Where INF, TAR COMESA and $T A R_{T P}$ are represented by $Y_{i t}$, and $U$ is represented by $X_{i t}, \alpha_{i}$ is country specific representing a fixed effect or individual-specific effect that is allowed to vary across individual crosssectional units, $\beta_{\mathrm{t}}$ is a time-specific error term that captures either shortrun external effects or long-run effects (both are global effects) that cause the variables of each country to move together over time and $\varepsilon_{\text {it }}$ denotes an error term (for more details, see Negem 2008).

Both slope coefficients $\delta_{\mathrm{i}}$ and the time effect $\beta_{\mathrm{t}}$ are modelled heterogeneously like intercept terms (Pedroni, 1999). A panel cointegration test developed by Pedroni (1999) is used to determine whether there is a stable long-run relationship, allowing for short run dynamics across countries under study. It also allows for heterogeneity of cointegrating vectors and controls for potential endogeneity of the regressors and serial correlation (Negem, 2008, 187).

\section{c- Vector Autoregressive (VAR) test using panel data}

In the absence of co-integration among variables, the causal relationship is examined between the above four variables using VAR. The VAR can be written as follows:

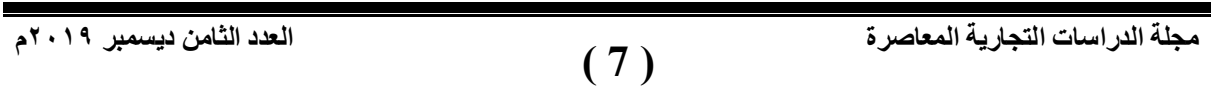


Seham Hamed Negem The Causal Relationship between Inflation and Unemployment

Denote $V$ as a four-component vector where $V=(U$,

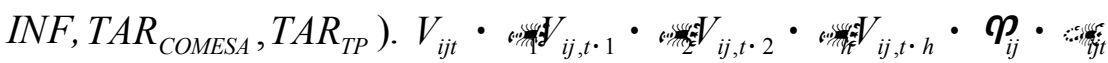

for $\mathrm{i}=$ variable and $\mathrm{j}=$ country.

Or it can be written for our model as follows (Negem, 2008):

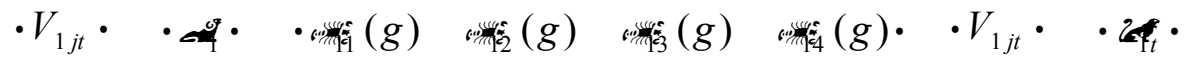





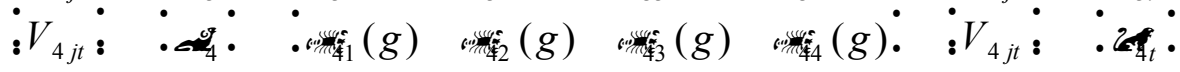

d- Vector Error Correction Model (VECM) using panel data:

Once cointegration is detected, the direction of causality must be determined within the context of a vector error correction model (VECM) (Granger, 1988). VECM represents a special case of VAR which imposes cointegration on its variables to allow distinction between short-run and long-run Granger causality. ECTs enable to avoid misspecification. For panel data the VECM model is specified as follows: specified as follows:

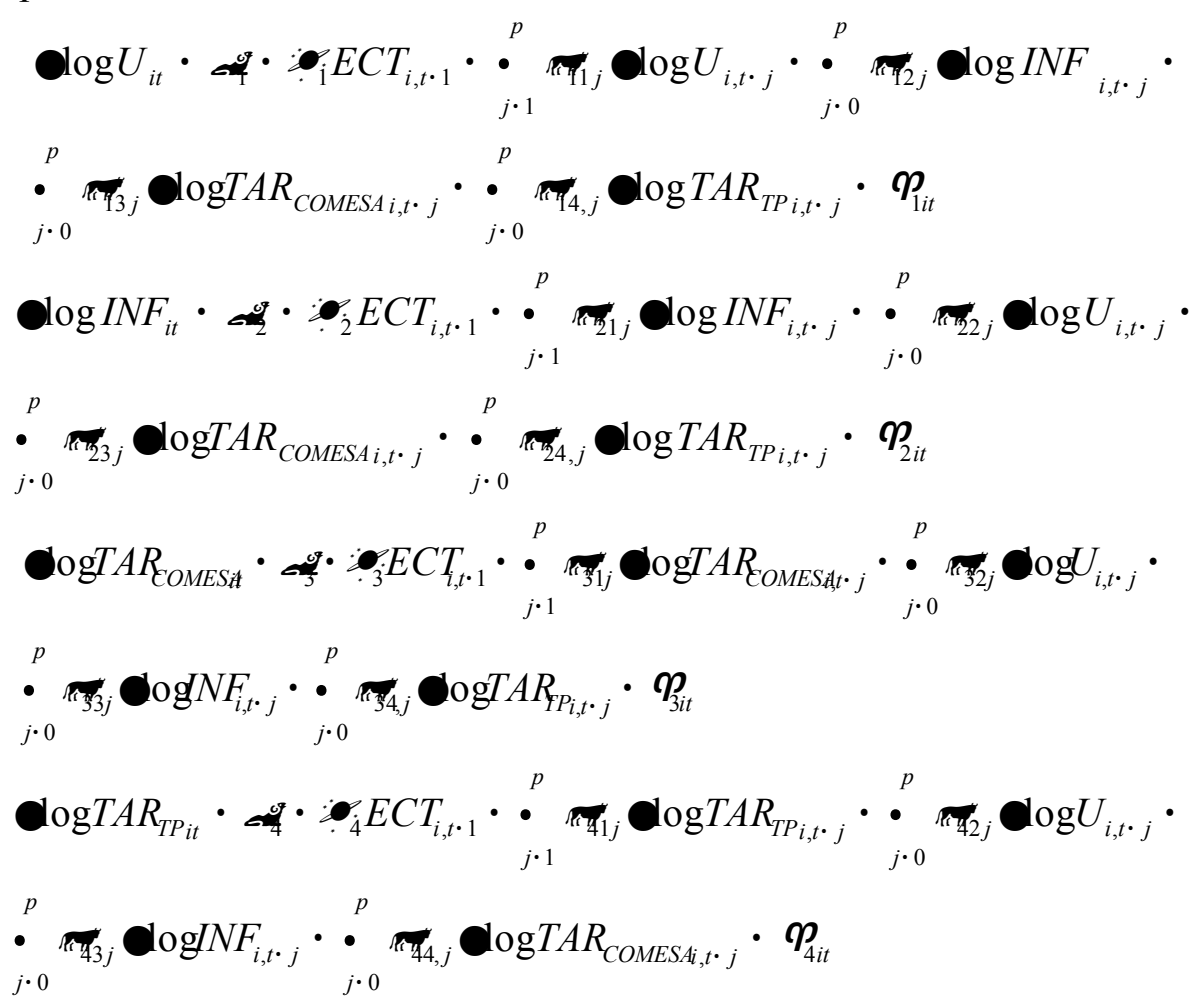

Where, $\Delta$ is the first-difference operator, the term $E C T_{i, t-1}$ (the previous period disequilibrium $)=$ 
$U_{i t \cdot 1} \cdot \hat{a}_{i} \cdot \hat{A R N F} F_{i t \cdot 1} \cdot \hat{n} A R_{\text {COMESA } i t \cdot 1} \cdot \hat{x} T A R_{T P i t \cdot 1} \cdot$ It is the error correction term derived from the long run cointegrating relationship, as the existence of this relationship indicates that we can use the residuals from the cointegration equation as $E C T$, the coefficients of $E C T ; \psi_{1}, \psi_{2}$, $\psi_{3}, \psi_{4}$ capture the adjustments of $\triangle U, \triangle I N F, \triangle T A R_{\text {COMESA }}$, and $\triangle T A R_{T P}$ towards long-run equilibrium.

With the presence of cointegration, at least one of the $\psi$ parameters is significant (non zero) when there is a long run relationship among the variables under study. The VECM can be estimated using two steps. The first step is using Johansen's (1988) maximum likelihood procedure to estimate the long run relationship among $U, I N F$, $T A R_{\text {COMESA }}$, and $T A R_{T P}$, as formulated in the VAR. The estimated cointegration relationship, obtained from the first step, is used to construct the disequilibrium term and then estimating VECM for each variable under consideration depending on the VECM equations stated above.

\section{e- Granger causality test using panel data:}

The question this paper tries to answer is, does inflation Grangercause unemployment? Since the cause always comes before its effect. When saying that one variable Granger- causes another variable; it actually means that the current value of the latter is conditional on the past values of the former and the former variable helps explain and forecast the latter one (Negem, 2008). The Granger causality test is employed to understand the nature of causation. The equation is specified as follows:

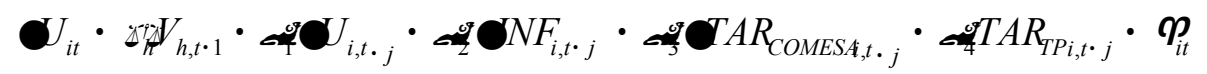

F-statistics can be used to verify the joint hypothesis that the coefficients of the independent (explanatory) variables equal zero. The Granger causality can be examined by a Joint Wald test applied to the coefficient of each independent variable in the VECM.

\section{Data and Empirical results of causality test:}

To examine the causality test for inflation and unemployment, the empirical work in this paper uses panel data of COMESA countries for the period 2000-2018. The sample includes 21 COMESA countries and their trading partners, shown in appendix 1 , both the members and nonmembers in the COMESA. The main variables of interest, as indicated, are Unemployment, as a dependent variable, is represented by unemployment rate. This dependent variable is obtained from WORLD FACTBOOK ARCHIVES (The World Face book, 2000-2018) available at cia.gov. Inflation, as the most important explanatory variable, is 
represented by inflation rate and obtained from the same source mentioned. Tariffs applied to the COMESA imports, TAR ${ }_{\text {COMESA }}$, and tariffs applied to the COMESA exports by its trading partners (as an average of both members and non members trading partners), $T A R_{T P}$, both variables are obtained from Common Market for Eastern and Southern Africa (COMESA) annual reports and United Nations Conference on Trade and Development (UNCTAD), both available at: http://comstat.comesa.int and http://www.comesa.int, and UNCTAD Database www.unctad.org/fdisstatistics, respectively. COMESA International Trade statistics Bulletin is used for collecting some data that updated using the IMF's International Financial Statistics, International Trade Centre available at www.intracen.org/itc/market-info-tools/tradestatistics/ and African Development Bank available at: afdb.org.

Since Libya joined COMESA in 2005 and Somalia and Tunisia joined in 201, some data values were missing. The available data of the tariffs have been obtained from the agricultural sector only.

The appropriate tests, indicated in detail in section 4, are employed to test for causality using GiveWin, Pc-Give.

\subsection{Unit Root test results:}

Table ( 1 )

Unit root test results (2000-2018)

\begin{tabular}{|c|c|c|}
\hline Variable & Level & First Difference \\
\hline$U$ & -1.47 & $-8.67^{*}$ \\
\hline$I N F$ & -1.53 & $-7.34^{*}$ \\
\hline$T A R_{\text {COMESA }}$ & -1.96 & $-6.89^{*}$ \\
\hline$T A R_{T P}$ & -1.99 & $-5.76^{*}$ \\
\hline
\end{tabular}

Notes: (1) $U$ is unemployment rate, INF is inflation rate, TAR COMESA is the tariff applied to imports, and $T A R_{T P}$ is tariffs applied to COMESA exports by its trading partners (members and non members)

(2) All data are in logarithmic form.

(3) For First Difference: the critical value at 1\% significance level is -3.64 .

(4) *signifies the rejection of the unit root hypothesis at $1 \%$ significance level.

As shown in table 1, the IPS test results on the level form of the above variables failed to reject the null of non-stationarity, however they reject this null as first differenced become stationary at the $1 \%$ significance level. Having established that the four variables are integrated of the first order, cointegration must be tested to determine if there is a long run relationship between these variables.

مجلة الدراسات التجارية المعاصرة




\section{Cointegration test results:}

Cointegration is tested based on residual for the null of no cointegration to detect long-run relationship among the set of integrated variables: $U, I N F, T A R_{C O M E S A}$ and TAR $R_{T P}$. If the residual seems stationary, this suggests that the variables are cointegrated. Cointegration test is carried out by examining the stationarity of the error term (ADF for residual) estimated from the following equation:

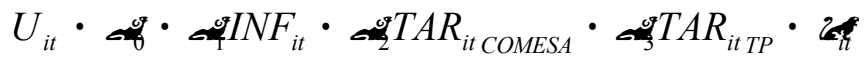

Table ( 2 )

Cointegration test results

\begin{tabular}{|c|c|}
\hline & $\begin{array}{c}\text { Panel-ADF statistics } \\
\text { Lag order }\end{array}$ \\
\hline$P_{i}=1$ & -1.98 \\
\hline$P_{l}=2$ & -3.55 \\
\hline$P_{l}=3$ & $-5.72^{*}$ \\
\hline$P_{i}=4$ & $-9.41^{*}$ \\
\hline$P_{i}=5$ & $-11.83^{*}$ \\
\hline
\end{tabular}

Note:* signifies the rejection of the unit root hypothesis of the residuals at $1 \%$ or (no cointegration hypothesis).

Allowing for five years lag length, the estimated panel $t$ statistics is higher than the critical value at the $1 \%$ level, indicating stationary residuals in the regression or cointegration among all variables. Hence, it can be concluded that there is a cointegrating relationship among the variables.

\section{Vector Error Correction Model (VECM) results:}

Table ( 3 )

Granger Causality based on VECM

\begin{tabular}{|c|c|c|c|c|c|}
\hline $\begin{array}{c}\text { Dependent } \\
\text { variables }\end{array}$ & $U$ & $\mathbf{O} N F$ & $T A R_{\text {COMESA }}$ & $\widehat{C} A R_{T P}$ & $\begin{array}{c}E C T \\
\text { Coefficient } \\
\text { t-ratio }\end{array}$ \\
\hline $\mathbf{I}$ & - & $\begin{array}{c}9.056 \\
(0.002)^{*}\end{array}$ & $\begin{array}{c}15.876 \\
(0.000)^{*}\end{array}$ & $\begin{array}{c}8.634 \\
(0.004)^{*}\end{array}$ & $\begin{array}{l}-0.016 \\
0.83\end{array}$ \\
\hline $\mathbf{C N F}$ & $\begin{array}{c}2.193 \\
(0.367) \\
\end{array}$ & - & $\begin{array}{c}7.943 \\
(0.001)^{*}\end{array}$ & $\begin{array}{c}0.985 \\
(0.164) \\
\end{array}$ & $\begin{array}{l}-0.136 \\
-2.23 \\
\end{array}$ \\
\hline $\mathrm{T}_{A} R_{\text {COMESA }}$ & $\begin{array}{c}18.334 \\
(0.000)^{*}\end{array}$ & $\begin{array}{c}11.827 \\
(0.000)^{*}\end{array}$ & - & $\begin{array}{c}6.653 \\
(0.003)^{*}\end{array}$ & $\begin{array}{l}-0.314 \\
5.92\end{array}$ \\
\hline$T A R_{T P}$ & $\begin{array}{c}2.087 \\
(0.095)\end{array}$ & $\begin{array}{c}1.076 \\
(0.658)\end{array}$ & $\begin{array}{c}5.127 \\
(0.002)^{*}\end{array}$ & - & $\begin{array}{c}-0.064 \\
4.88 \\
\end{array}$ \\
\hline
\end{tabular}

Notes:

(1) $\Delta$ is the first operator

(2) * denotes statistically at $1 \%$ level 
(3) The significance of the error correction term $(E C T)$ is evaluated with t-statistics

(4) Wald test tests the jointly significance of the lagged values of independent

Variables. $\mathrm{H}_{0}: \mathrm{a}_{2}=\ldots \ldots \ldots=\mathrm{a}_{4}=0$ which is verified at $1 \%$ and $5 \%$ significance levels.

(5) Numbers in parentheses are the P-values.

Table (3) presents the results of the Granger causality test within the VECM framework using panel data for the full sample countries. The whole sample panel shows, in the short-run, the existence of unidirectional causality running from inflation (INF) towards unemployment $(U)$ as well as a unidirectional causality running from the tariff applied by COMESA trading partners to COMESA exports $\left(\boldsymbol{C} A R_{T P}\right)$ to unemployment.

The long run causality is not detected for the unemployment and inflation equations since t-statistics are low (i.e. ECT is statistically insignificant). For both equations of the tariff applied by COMESA to imports $\left(\boldsymbol{T} A R_{\text {COMESA }}\right)$ and the tariff applied by COMESA trading partners to COMESA exports $\left(\boldsymbol{T} A R_{T P}\right) E C T$ is statistically significant at $1 \%$ level, verifying the existence of the long run relationship among some of variables indicated in these equations.

Bidirectional causality exists between inflation (INF) and the tariff applied by COMESA to imports ( $T A R_{\text {COMESA }}$ ) as well as between the tariff applied by COMESA to imports ( $\boldsymbol{C} A R_{\text {COMESA }}$ ) and the tariff applied by COMESA trading partners to COMESA exports ( $\left.\boldsymbol{C} A R_{T P}\right)$. Finally, third bidirectional causality exists between unemployment $(U)$ and the tariff applied by COMESA to imports ( $T A R_{\text {COMESA }}$ ). 


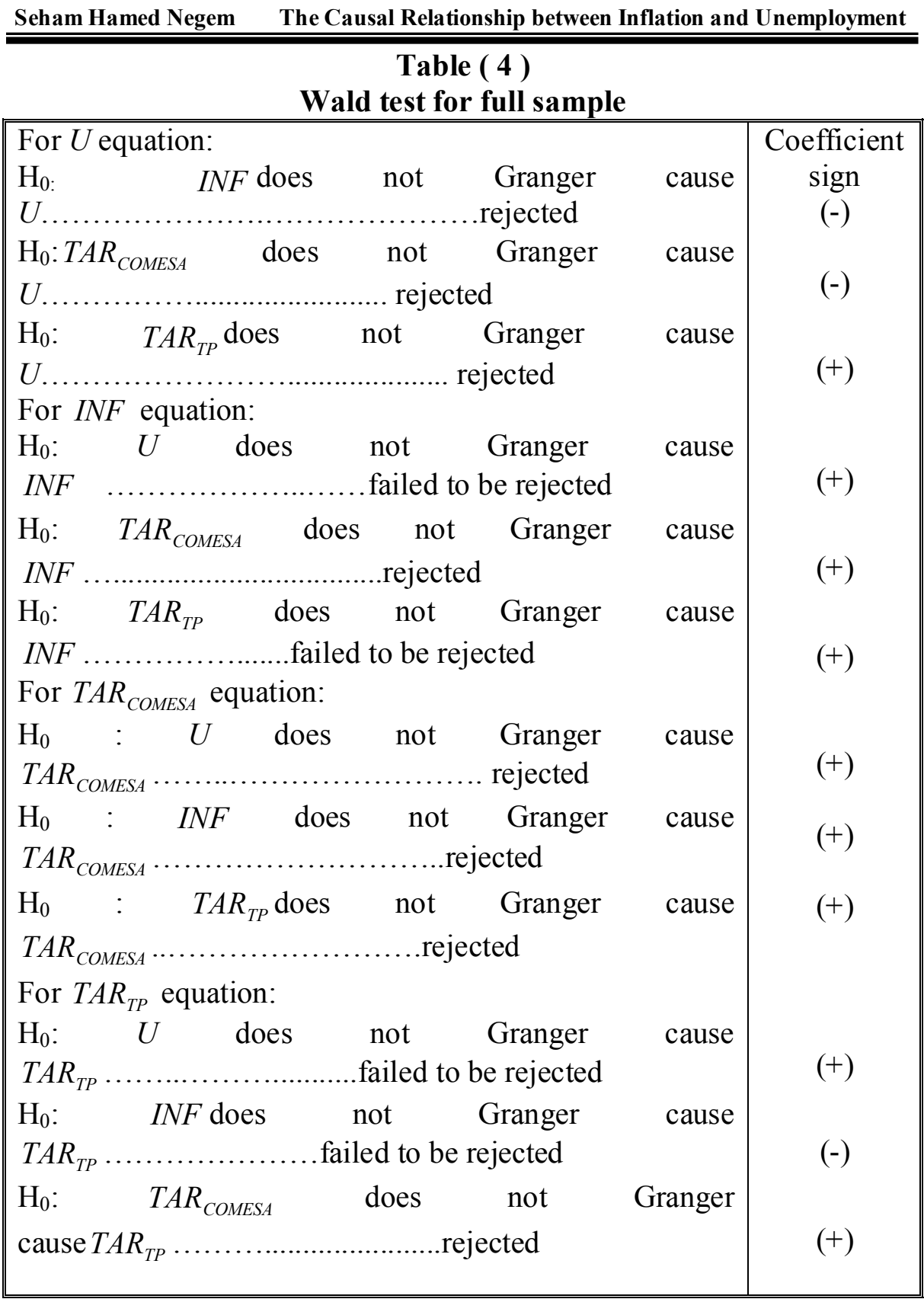

Note: the rejection of null is based on the statistics in Table 3 obtained from the estimation of VECM

The estimated coefficients for carrying out the Wald test, for the null of no causality, are reported in table 4 by calculating F-statistic based on the null hypothesis that a set of coefficients on the lagged values of the independent variables (the other three variables and the error correction 
adjustment term) are jointly equal to zero. To accept the null hypothesis means that the independent variables do not cause the dependent one.

In the $U$ equation, there are three null hypotheses: For the most important aim, that is to investigate whether inflation cause unemployment or unemployment cause inflation the Wald test in this equation indicates that causality runs from inflation to unemployment as the test rejects the null of no causality at the $1 \%$ significance level. On the other hand, via the $I N F$ equation the evidence indicates that causality is not running from unemployment to inflation. Therefore, it may be concluded that evidence indicates a unidirectional causality running between inflation and unemployment.

\section{Concluding Remarks:}

This paper addresses whether there is any causal effect between inflation and unemployment. For the period 2000-2018, panel data of COMESA2 1 countries are used to investigate the causality between the mentioned variables within the Vector Error Correction Model (VECM) framework. By using GiveWin, Pc-Give, the appropriate tests are employed to examine the relationship between the mentioned two variables.

The IPS test results reject the null of non-stationarity when the model variables, $U, I N F, \boldsymbol{T} A R_{\text {COMESA }}$ and $\boldsymbol{\widetilde { T }} A R_{T P}$, have been first differenced at the $1 \%$ significance level. Cointegration test is applied by examining the stationarity of the error term, i.e. ADF for residual. The Cointegration test indicates stationary residuals at the $1 \%$ level in the regression, i.e, cointegrated variables. This test is carried out by Allowing for five years lag length. The direction of causality is determined within the context of a vector error correction model (VECM). For the null of no causality, the Wald test used the estimated coefficients to be carried out by calculating F-statistic. Accepting the null hypothesis means that the independent, explanatory, variables do not cause the dependent, explained, one.

The results documented that there is a unidirectional relationship running from inflation to unemployment in the short run, but this is not true when the relationship runs in the opposite direction. In the long run, for unemployment and inflation equations, the error correction term, $E C T$, is statistically insignificant, verifying the absence of the long run relationship among the two variables of interest. 


\section{References}

1. ABU, N., (2017), " Inflation and Unemployment Trade-Off: A Reexamination of the Phillips Curve and Its Stability in Nigeria", Contemporary Economics, 13, NO.1:21-34.

2. AL-ZEAUD, H. A., (2014), " The Trade-Off between Unemployment and Inflation Evidence from Causality Test for Jordan", International Journal of Humanities and Social Science, 4, NO.4: 103-111.

3. BHATTARAI, K. (2016), "Unemployment-inflation trade-offs in OECD countries", Economic Modelling, 58, 93-103.

4. DOORNIK, J. A. \& HENDRY, D. F., (2003), Pc-Give Volume I-III, London, Give Win Timberlake Consultants Limited.

5. DRITSAKI, C. \& DRITSAKI, M., (2013), "Phillips Curve inflation and Empirical Research for Greece", Computational Economics and Econometrics, 3, NO.1/2.

6. DUTT, P., MITRA, D. \& RANJAN, P., (2008), "International Trade and Unemployment: Theory and Cross-National Evidence: Faculty\& Research, Working Paper", INSEAD The Business School for the World.

7. FURUOKA, F., (2008), "Unemployment and Inflation in the Philippines: New Evidence from Vector Error Correction Model", Philippine Journal of Development, XXXV, NO.1: 93-106.

8. FURUOKA, F.,(2007), "Des the "Phillips Curve" Really exist? New Empirical Evidence from Malaysia", Economics Bulletin, 5, NO.16: pp. 1-14.

9. GRANGER, C. W. J., (1988), "Some Recent Developments in a Concept of Causality", Journal of Econometrics, 39, NO.1-2: pp. 199211.

10. HASAN, R., MITRA, D., RANJAN, P. \& AHSAN, R. N., (2010), "Trade Liberalization and Unemployment: Theory and Evidence from India", Department of Economics, The Maxwell School, Syracuse University, Syracuse, pp.1-37.

11. IM, K. S., PESARN, M. H. \& SHIN, Y., (1998), Testing for Unit Roots in Heterogeneous Panels, Dept. of Applied Economics, Cambridge University.

12. JOHANSEN, S., (1988), "Statistical Analysis of Cointegration Vectors", Journal of Economic Dynamics and Control, 12, NO.2-3: pp. 231-254.

13. MAXIMOVA, A., (2015), "The Relationship between Inflation and Unemployment: A Theoretical Discussion about the Philips Curve", Journal of International Business and Economics, 3, NO.2: 89-97. 
14. NEGEM, S., (2015), "Tariffs and Unemployment Causality: Evidence from A Panel

15. Analysis of the EU", Proceedings of "Second European Academic Research

16. Conference on Global Business, Economics, Finance and Banking”, July, Zurich, Switzerland, Available at: http://globalbizresearch.org/Swiss Conference/Conference Papers.php

17. NEGEM, S., (2008), Free Trade and Economic Growth of Egypt, PhD thesis, Hull University, England.

18. PEDRONI, P., (1999), "Critical Values for Cointegration tests in Heterogeneous Panels with multiple Regressors", Oxford Bulletin of Economics and Statistics, 61, 653-670.

19. PHILLIPS, A. W., (1958), " The Relationship Between Unemployment and the Rate of Change of Money Wage Rates in the United Kingdom, 1861-1957", Economica, 25, NO.Nov.: 283-299.

20. SAMUELSON, P. \& SOLOW, R., (1960), " Analytical Aspects of Anti-Inflation Policy", American Economic Review, 50, NO.2: 177194.

21. SASONGKO, G. \& HURUTA, A. D., (2019), " The causality between Inflation and Unemployment: The Indonesian Evidence", Verslas: teorija ir praktika/ Business; Theory and Practice, 20, 1-10.

22. STEPHEN, O., FAVOUR, O. E., OKORO, T. \& NWACHUKWU, J., (2017), "Understanding the Relationship between Unemployment and Inflation in Nigeria", Journal of Poverty, Investment and Development, 35. 


\section{Appendix 1}

COMESA countries and their Trading Partners

\begin{tabular}{|c|c|c|c|}
\hline Ser. & Country & Exports-partners & Imports-partners \\
\hline 1. & Burundi (1981) & DRC, Switzerland, \&UAE & India, China, \&Kenya1 \\
\hline 2. & Comoros (1981) & France, India, \& Germany & UAE, France, \&China \\
\hline 3. & Democratic & China, Zambia, \& South & China, South Africa, \& \\
\hline 4. & $\begin{array}{l}\text { Republic of the } \\
\text { Congo (1981) } \\
\text { Diibouti (1981) }\end{array}$ & Korea & Zambia \\
\hline 5. & Egypt (J1999) & Ethiopia, Somalia, \& Qatar & UAE, France, \& Saudi \\
\hline 6. & Eritrea (1994) & UAE, Italy, \& US & Arabia \\
\hline 7. & Eswatini (1981) & China \& South Korea & China, UAE, \& Germany \\
\hline & $\begin{array}{l}\text { (the former } \\
\text { name was }\end{array}$ & $\begin{array}{l}\text { South Africa } 94 \% \text { of total } \\
\text { exports }\end{array}$ & $\begin{array}{l}\text { UAE, China, \& Saudi } \\
\text { Arabia }\end{array}$ \\
\hline 8. & Swaziland) & & South Africa \& China \\
\hline 9. & Ethiopia (1981) & & \\
\hline 10. & Kenya (1981) & Sudan, Switzerland, \&China & \\
\hline 11. & Libya (2005) & Uganda, Pakistan, \& US & China, Saudi Arabia, \& \\
\hline & Madagascar & Italy, Spain, \& France & India \\
\hline 12. & (1981) & France, US, \& China & China, India, \&UAE \\
\hline 13. & Malawi (1981) & & China, Turkey, \& Italy \\
\hline 14. & Mauritius & Zimbabwe, Mozambique, \& & China, India, \& France \\
\hline 15. & (1981) & Belgium & \\
\hline & Rwanda (1981) & France, US, \& UK & South Africa, China, \& \\
\hline 16. & Seychelles & UAE, Kenya, \& Switzerland & India \\
\hline 17. & (2001) & UAE, France, \& UK & India, China, \& France \\
\hline 18. & Somalia (2018) & & China, Uganda, \& India \\
\hline 19. & Sudan (1981) & Oman, Saudi Arabia, \& UAE & UAE, France, \& Spain \\
\hline 20. & Tunisia (2018) & UAE, Egypt, \&Saudi Arabia & \\
\hline 21. & Uganda (1981) & France, Italy, \& Germany & China, India, \& Ethiopia \\
\hline & Zambia (1981) & Kenya, UAE, \& DRC & UAE, Egypt, \& India \\
\hline & Zimbabwe & Switzerland, China, \& DRC & Italy, France, \& China \\
\hline & (1981) & South Africa, Mozambique, & China, India, \& UAE \\
\hline & & $\& \mathrm{UAE}$ & South Africa, DRC, \& \\
\hline & & & South Africa \& Zambia \\
\hline
\end{tabular}

Source: The World Face book-CIA

Notes: 1. Angola (2007), Lesotho (1997), Mozambique (1997), Namibia (2004), and Tanzania (2000) were former members and excluded from the sample.

2. DRC is Democratic Republic of the Congo.

3. The numbers between the brackets are the joining year to COMESA. 